\title{
'Maskenin Arkasındaki Sır’ Düğün ve Toplumsal Cinsiyet Eşitsizliği
}

\author{
'The Secret behind the Mask' Wedding and Gender Inequalitiy
}

\section{Halime ÜNAL REŞITTOĞLU*}

Öz: Din, ırk ve sınıf fark etmeksizin her toplumda insanlar evlenmekte ve bu birlikteliklerini düğün ile taçlandırmaktadırlar. Düğünler çiftlerin aşkı ve birbirine olan bağlılıklarının sembolü olmakla beraber toplumsal cinsiyet eşitsizliğini yaratan ataerkil ve heteroseksüel ilişkileri taşıyan ritüellerdir. Geleneksel toplumsal cinsiyet rolleri sosyalizasyon sürecinde öğrenildiği ve kurumların çoğunluğu toplumsal cinsiyetçi mesajlar verdiği için düğün ritüellerinin bu eşitsizliği nasıl yarattığını görmek kolay değildir. Bundan dolayı, çoğunlukla, kadınların erkeklere niçin evlenme teklif edemediğini, erkeğin niçin kızın annesinden değil de babasından evlenmek için izin aldığını, düğünde niçin herkesin gözlerinin gelinin üzerinde olurken erkeğin üzerinde olmadığg, neden damatlıktan değil de gelinlikten daha çok konuştuğumuz gibi soruları sormak aklımıza gelmemektedir. Düğünler toplumsal cinsiyet ideolojisini pekiştiren ve kadın ve erkekleri toplumsal cinsiyetlendirmiş performs sergilemekten sorumlu tutan güçlü ritüellerdir. Kadını feminen ve erkeği maskulen özneler olarak inşa eden düğünler ataerkil baskın toplumsal düzeni devam ettirmenin güçlü bir aracıdırlar. Bu bağlamda, bu çalışmanın amacı toplumsal cinsiyetlendirilmiş bir ritüel olarak düğüne 1şık tutmaya çalışmaktır.

Anahtar sözcükler: Düğün, Toplumsal Cinsiyet, Ataerkillik, Heteroseksüellik, Feminenlik, Maskulenlik

\begin{abstract}
Regardless of religion, race and class in every society, many people are getting married and glorify their marriage with a wedding. Although a wedding is the symbol of the couple's love and commitment to each other, it is at the same time an important tradition which ritualizes patriarchal and heterosexual gender relations which create gender inequality. It is difficult to see how wedding rituals construct this inequality because people are socialized to traditional gender roles and many institutions provide gendered messages. Therefore, most of the time, we do not ask questions such as why women cannot propose to men, why men need to obtain permission to get married from the women's father but not from the mother, why everyone' eyes focus on the bride but not on the groom, why we are talking about the bride's wedding dress but not about the dress of the groom. Weddings have a powerful course of events which reinforce gender ideologies and hold women and men responsible for their gender performances. Weddings, which construct women as feminine and men as masculine subjects, become a powerful way to secure the dominant patriarchal social order. In this context, the aim of this paper is to try to cast a light on weddings as gendered rituals.
\end{abstract}

Keywords: Wedding, Gender, Patriarcy, Heterosexuality, Femininity, Masculinity

Düğün bireylerin bekarlıktan çift olmaya ve yeni bir aile kurmaya geçtikleri aşamayı simgeler. Düğün o kadar güçlü bir ritüeldir ki, uzun yıllar beraber yaşayan çiftler bile, ilişkilerinin ne

\footnotetext{
* Doç. Dr. Ankara Yıldırım Beyazıt Üniversitesi, İnsan ve Toplum Bilimleri Fakültesi, Sosyoloji Bölümü, Ankara. unalhalime@hotmail.com
} 
kadar ciddi olduğunu göstermek için evliliklerini dügün töreni ile taçlandırarak beraber yaşayan çift olmaktan aile olmaya geçtiklerini ilan ederler (Boden 2003). Çiftler, akraba ve arkadaşlara, artık haylaz çocuklar olmaktan çok sorumluluk sahibi olan kadın ve erkek olduklarını dügün ile kanıtlarlar. Başka bir ifade ile, çiftlerin bir toplumsal statü ve rolden başka bir statü ve role geçişinin onaylanmasını sembolize eden düğün ritüelleri çiftlerin yeni konumları ile ilgili değer ve normları da aktarmaktadır. Bu bağlamda, düğünler evlilik kurumu ile ilişkili olan değer ve normlar sistemini çiftlere aktarırken baskın olan ataerkil sistemin, heteroseksüelliğin ve toplumsal cinsiyetin de sürekli inşa edilmesini sağlarlar (Ingraham 1999; Otnes \& Pleck 2003; Besel et al. 2009; Fairchild 2014). Dügün feminenliğin ve maskulenliğin abartılı olarak sergilendiği çiftler arasındaki iktidar ilişkilerinin doğalmış gibi sunularak teşvik edildiği, baskın olan kültürel norm ve değerlerin aktarıldığı bir ritüeldir. Düğün öncesi ve düğün esnasındaki ritüellerle kadınlık ve erkeklikle ilgili normlar ve beklentiler hem bireylere aktarılır hem de normlara uygun davranmaları sağlanır. Düğünle ilgili normatif beklentilerin içine gömülü olan toplumsal cinsiyet inşasını görmek oldukça zordur. Çünkü düğün bir maske gibi toplumsal cinsiyet eşitsizliğini gizler. Dügünler o kadar doğaldır ki, evlenecek olan kadın ve erkeğin yapması gereken şeyler ve uyması gereken kurallar uzun zamandır benzer şekillerde yapıldığ 1 için düğünün yarattığı eşitsizliği ve baskın olan normatif sistemi aktarma sürecini görmek güçleşmektedir. Bundan dolayı, bu çalışma, düğün ritüellerine, dügüne verilen anlama ve dügünle ilişkili sembollere odaklanarak dügün aracılığı ile toplumsal cinsiyet inşasının ve eşitsizliğinin nasıl yaratıldığına 1şık tutmayı amaçlamaktadır. Öncelikli olarak, kısa bir şekilde toplumsal cinsiyet kavramı etikileşimsel ve yapısal bir unsur olarak tartışıldıktan sonra ataerkilliğin izini taşıyan bazı düğün ritüellerine odaklanılacak, düğünün kadın ve erkek için anlamları ve mükemmel gelin imgesi sorgulanmaya çalışılacaktır.

\section{Toplumsal Cinsiyet Tartışması}

Bu çalışma kapsamında toplumsal cinsiyet etkileşimsel ve yapısal bir olgu olarak tartış1lacaktır. Düğün ritüellerinde, toplumsal cinsiyet gündelik aktiviteler aracılığı ile sürekli yaratılırken, aynı zamanda, bireylerden bağımsız olarak toplumsal cinsiyetlendirilmiş bir yapı mevcut olduğundan ritüelleri gerçekleştirirken bireyler özgür değildirler. Öncelikli olarak toplumsal cinsiyet etkileşimsel olarak kavramsallaştırıldığında, biyolojik-anatomik farklılıkları temel alan cinsiyetin basit bir yansıması olmadığ 1 gibi, bireylerin sosyalizasyon sürecinde öğrendiği ve tamamladığ bir konum, statü ve rol de değildir. Toplumsal cinsiyet bireysel bir nitelik değil, bizim ne olduğumuzdan çok, ne yaptığımızdır veya performansımızdır. Toplumsal cinsiyet, gerçekleştirmekten sorumlu tutulduğumuz birşeydir (West \& Zimmerman 1987). Toplumsal cinsiyet, kadınlık ve erkeklikle ilgili normatif beklentiler çerçevesinde gündelik etkileşimler esnasında sürekli yaratılır ve normatif beklentileri ne derece karşıladığına göre değerlendirilir. Birey, sürekli olarak normatif beklentilere uygun davranarak toplumsal cinsiyetini tekrar inşa etmelidir veya yaratmalıdır (West \& Zimmerman 1987). Toplumsal cinsiyet etkileşimsel olduğu kadar yapısaldir da (Connell 1987; Lober 1994; Martin 2004; Ridgeway \& Correll 2004; Risman 2004). Tarihsel olarak toplumsal cinsiyet, kadın ve erkek arasındaki farklılıkları yaratır, pekiştirir ve eşitsizliği meşrulaştırmak için vardır (Lober 1904). Aile içinde, iş yaşantısında, eğitimde, hatta sokakta ve daha bir çok kurumun içinde toplumsal cinsiyet gömülü olarak vardır ve eşitsizlik görünmez kılınmaktadır (Connell 1987; Martin 2004). Yap1 olarak toplumsal cinsiyetin bireysel boyutu, etkileşim boyutu ve kurumsal boyutları vardır (Risman 2004). Bireysel düzeyde, sosyalizasyon sürecinde bireyler toplumsal cinsiyetlerini öğrenirler, kendilerini toplumsal cinsiyet gözünden tanımlamaya başlarlar. Kadınlık ve erkeklikle ilgili beklentilere göre yetiştirilirler. Kadınlar küçük yaşlardan beri kırılgan, narin, duygusal, empatik, başkalarının ihtiyaçlarını 
kendi ihtiyaçlarının önüne koyan, fedakar, pasif, güçsüz ve itaatkar olarak yetiştirilirler. Erkekler ise kadınlığın dışında kalan güç ve iktidarla ilişkili beklentiler sistemine göre yetiştirilirler. Erkeklik, iktidar ile ilişkilendirilirken kadınlık, itaatkar olmakla ilişkilendirilir. Kadınlıkla ilgili normatif beklentilerin kültürel olarak değersizleştirilmesi ile, erkeklik ayrıcalıklı hale gelerek toplumsal cinsiyetler arasında bir iktidar ilişkisi kurulur (Connell 1987). Örneğin, erkekler kadın gibi ağlamaz veya erkekler ağlamaz dendiğinde kadın olmak ve ağlamak zayıflık ve kırılganlıkla ilişkilendirilerek değersizleştirilir ve bu bir erkek için istenmeyen bir durumdur. Kadınlık ve erkeklik hakkındaki normatif beklentilere yüklenen anlamlar eşitsiz olduğu için gündelik etkileşimler esnasında bu beklentilere uygun davranan kadın ve erkekler görünmeyen eşitsizliği sürekli yaratırlar (Ridgeway \& Corell 2004). Aslında onların tek yaptığı şey normatif beklentileri karşılamak ve ötekileştirilmemek için kadın ve erkek gibi davranmaya çalışmaktan başka birşey değildir. Bireylerin davranışları ile beraber yaşamın her alanı toplumsal cinsiyetlendirilmiştir. Kurumlar, örgütler, meslekler ve toplumsal yaşamdaki diğer unsurlar toplumsal cinsiyetlendirilmiş anlamlara sahiptir (Acker 1992; Ridgeway \& Corell 2004). İşlerin kadın işi erkek işi olarak ayrışması, erkeklerin daha çok kazanırken kadınların daha az kazanması, kadın ve erkekler için sağlık olanaklarının farklı olması, baba ve çocuk sağlığı ocakları yok iken ana ve çocuk sağlığı ocaklarının olması, kadınlarla ilgili yasal düzenlemelerin erkeklerden farklı olması, kadınların daha erken yaşta emekli olması, sokaklar kadınlar için güvensiz hale gelirken erkeklerin sokakların efendisi olması gibi birçok uygulama toplumsal cinsiyetin toplumsal yapının içinde hiç kendini fark ettirmeden çok doğalmış gibi yer aldığının işaretidir. Görüldüğü üzere, toplumsal yapının farklı boyutlarında toplumsal cinsiyetler arasındaki güç eşitsizliği gizlendiği ve görünmez kılındığı için bize o kadar doğal gelmektedir ki Lober'in $(1994,13)$ ifadesi ile "birçok insan için toplumsal cinsiyet hakkında konuşmak balığın su hakkında konuşması gibidir". Bundan dolayı, düğün ve ilişkili ritüelleri incelemek, görünmez kılınanı ve doğallaştırılanı görünür kılmak için fırsat tanımaktadır. Erkeğin evlilik teklifi yapması normal karşılanır, ama kadının yapması neden karşılanmaz, neden kız istenir de erkek istenmez, gelin alma töreninin karşıllı̆ında damat alma töreni neden yoktur, niçin kadınlar küçük yaştan itibaren evlenmeyi evinin kadını olmayı hayal ederken erkekler etmez, gelinin ilgili kültürün normları bakımdan güzel olması damatın güzel olmasından niçin daha önemlidir gibi soruları genellikle sormak çok gereksiz gibidir.

\section{Seçen Erkek Seçilen Kadın}

Evlilik teklifi, çiftlerin ilişkisinin ciddi olduğunun ve bekarlıktan evli olmaya doğru adım attıklarının sembolü olmakla beraber ataerkilliği, heteroseksüelliği ve toplumsal cinsiyet eşitsizliğini beslemektedir. Kadın ve erkeğin toplumsal cinsiyete göre kendilerine konumlandırdıkları bir ritüel olan evlilik teklifi, kadın ve erkek arasındaki eşitsiz güç ilişkisini pekiştirmekte ve erkeğin kadın üzerinde iktidarını sağlamlaştırmaktadır. Heteroseksüel çiftlerde erkeğin evlilik teklifinde bulunması bir norm halini almıştır. Ne kadar aşık olurlarsa olsunlar, kadınların erkeklere evlilik teklifinde bulunması pek de makul karşılanmaz. Kadınların evlilik teklif etmesi kültürel normlardan saptığı için çoğu zaman bu teklif şaka olarak görülüp ciddiye alınmaz (Schweingruber, Anahita \& Berns 2004). Çiftlerin ilişkisinde dönüm noktası olacak kararı alan erkektir. Her ne kadar kadınlar teklif öncesinde dolaylı veya doğrudan evlilik hakkında erkeklere mesajlar verseler de, erkek, teklifin ne zaman, nerede ve nasıl olacağına karar veren kişidir. Evlilik teklifine giden yolu açan ve süreci başlatan kişi erkek iken kadın ise kabul edendir veya tamamlayıcı konumundadır. Başka bir ifade ile, erkek seçen, kadın seçilendir (Bestel et al. 2009). Erkek birçok kadın içinden o kadını kendine eş olmaya layık görmüş ve onu seçmiştir, kadın ise layık görülen ve seçilendir. Evlilik teklifinin erkekten gelmesi erkeğin ilişkide daha 
fazla güce sahip olduğunu göstermektedir. Erkek yaşanan ilişkinin evliliğe gidip gitmeyeceğine karar verme gücüne sahiptir. Bu kadının ilişkide karar alma sürecinde güçsüz veya pasif olduğunun göstergesidir.

Meşru bir evlilik teklifinin taşıması gereken şartlar vardır; evlenme teklif eden bir erkek ve beraberinde erkeğin alım gücüne işaret eden bir nişan yüzüğüdür (Schweingruber et al. 2004). $\mathrm{Bu}$ iki öğe birarada olmaz ise evlilik teklifinin samimiyetinden şüphe duyulmaktadır. Kadın, erkeğe evlilik teklifi yaptığında meşru bir teklif olarak görülmediği gibi erkeğin kadına yüzük almadan yapmış olduğu teklifin ciddiliği konusunda şüphe duyulur ve teklif gerçek bir teklif olarak görülmez. Erkek ve yüzük, özellikle de pırlanta yüzük, bir arada olmalıdır. Ucuz bir yüzük erkeğin kuracağı ailesini destekleyecek ekonomik güce sahip olmadığının işareti olarak yorumlanır (Howard 2003; Schweingruber et al. 2004). Erkeğin yüzüğü kadına vermesi ve parmağında taşıması kadının artık bir erkeğe ait olduğunun kanıtıdır (Howard 2003). Kadınlar erkeklerin romantik ve süpriz bir şekilde evlilik teklifi yapmasını beklerler. Romantik evlilik teklifinin göstergesi arasında erkeğin romantik bir ortam hazırlamış olması ve en önemlisi kızın önünde diz çökerek bu teklifi gerçekleştirmesidir (Schweingruber, Cast \& Anahita 2008). Erkeğin kadına yapmış olduğu teklif diğer şahışların gözünde de ciddiye alınmalıdır. Üçünçü şahışlar, erkekler diz üstüne çöker ve ellerinde pırlanta bir yüzük olursa, teklifin ciddiyetinden ve samiyetinden şüphe duymamaktadırlar (Schweingruber et al. 2008). Batı kültüründe norm haline gelen diz çökerek evlilik teklifi yapma geleneğinin ülkemizde de ünlüler arasında ve sosyal medyaya yansıyan evlilik teklifi görüntülerinde sıklıkla yer aldığı görülmektedir. Örneğin, ünlü oyuncu Burak Özçivit'in oyuncu Fahriye Evcen'e süpriz bir şekilde diz çökerek evlenme teklif ettiği video sosyal medyada romantizmin göstergesi olarak birçok defa paylaşıldı. Dügün daha çok kadınla ilgili olmakla beraber evlilik teklifi erkeğin parladığı, sahne 1şıklarının erkeğin üstüne döndüğ̈ bir andır. Erkek bunun için planlar yapar, hatta bazen arkadaş grubunu da bu planlara dahil ederek teklifi kadının hiç beklemediği anda ve süpriz bir şekilde yapar. Teklifin yaratacı olması için mesai harcaması beklenir. Bazen bir futbol maçında, bir konserde veya bir tv programında, köprüde, vapurda, markette, pankart açarak, önde giden aracın arkasına yazı yazdırarak, havada veya suyun altında birçok yaratıcı fikir ile teklif hazırlanır. Erkeğin maskulenliğini gösterdiği ve erkek olarak kendi değerini sergilediği bir andır (Schweingruber et al. 2004; 2008). Medyada yaymlanan reklamlar ve programlarda evlilik teklifinin erkek tarafindan yapılması gerektiği konusunda da sürekli mesajlar verilir. Örneğin, Show TV'de yayınlanan "Gelin Evi” adlı programda, gelinler eşleri ile nasıl tanıştıklarını ve evlilik teklifinin nasıl gerçekleştiriğini anlatırlar. Eğer gelinler teklif almadılar ise, program aracılığı ile eşlerine mesaj göndererek, evli oldukları halde, hala romantik bir teklif beklentisi içinde olduklarını iletirler. Evlilik teklifi almış gelinler ise, videolar veya fotoğraflar eşliğinde tekliflerini göstermektedirler. Teklif ne kadar romantik, yaratıcı ve beklenmeyen bir anda olur ise, gelinler tarafindan hayranlıkla karşılanmaktadır. Teklif almış fakat yeterince romantik olmadığını düşünen gelinlerde ise bir hayal kırıklığı olduğu anlaşılmaktadır. Otnes ve Pleck (2003) sıradan evlilik tekliflerinin kadınlara yaşatmış olduğu hayal kırıklığının kolaylıkla geçmediğini ve çiftlerin evliliklerinin ilk yıllarında tartışma konularından biri haline geldiğini belirtirler. Evlilik teklifi aynı zamanda çiftlerin, özellikle kadınların, başkaları ile paylaştığı bir hikayedir. Teklif hakkında diğerlerinin ne düşündüğü önemlidir. Sıradan bir teklif diğerlerinin gözünde erkeğin kadına pek değer vermediğinin göstergesi olarak anlaşllabilir. Yüzügün olmamas1, romantizm veya süpriz unsurunun eksikliği erkeğin erkeklik hiyerarşisinde daha alt sıralarda olduğuna işaret edebileceği gibi, kadının anlattığı gibi ilişkinin pek ciddi olmadığı, erkek tarafından kadına değer verilmediği, erkeğin kadınla oynadığ 1 veya oyaladığ gelebilir. Bundan dolayı, evlilik teklifi sadece erkeğin kadına yaptığı bir teklif olmasının 
ötesinde diğerleri için sergilenen bir performanstır aynı zamanda.

Evlilik teklifinin tam olarak meşruluk kazanması veya toplum tarafından onaylanması için erkeğin kızı ailesinden istemesi veya ailenin rızasını alması gerekmektedir. Batı kültüründe erkeğin kızın babasının rızasını alması beklenir (Pepin et al. 2008; Schweingruber et al. 2004). Ülkemizde de kız isteme töreni ile aile üyelerinin ama özellikle kızın babasının rızası alınır. Çocukların bakım ve yetiştirilmesinden sorumlu olan ve çocuklarına babadan daha fazla zaman ve enerji harcayan annenin değil de babanın rızasının alınması, kadının babanın kontrolünden evleneceği erkeğin kontrolüne geçisini sembolize eder. Kadınların kendi başlarına karar alabilecek güce ve yetkinliğe sahip olmadığı, daha çocuk oldukları ve bağımsız aktörler olmadıklarının sembolüdür (Schweingruber et al. 2004). Kız isteme ritüeli sırasında erkeğin erkekliğinin ve kadına olan sevgisinin test edildiği anlarda mevcuttur. Tuzlu kahveyi içip içmediği konusu kız isteme sırasında ve sonrasındaki anlatılarda sıklıkla gündeme gelmektedir. Gözlemlerimize dayanarak, tuzlu kahvenin damata sunulduğu anla ilgili video çekimi de birçok çiftte mevcuttur. Erkek kahveyi içtiğinde dayanıklılığını kanıtlamış ve sevdiği için gözünü budaktan sakınmayacağı mesajını vermiştir. Kadın için gurur verici bir durumdur çünkü erkeği onu maçhup etmemiştir. İçememesi veya içmekte zorlanması ise dalga geçilmeye maruz kalmayı getirmektedir. Böyle durumlarda kadınlar üçünçü şahıslara kahvenin ne kadar çok tuzlu olduğu veya zaten kendisinin içmesini istemediği gibi çeşitli rasyonelleştirmeler ile aslında erkeğin güçsüz olmadığını açıklamaya çalışır. Kadın bir erkekten diğer erkeğe transfer edilirken erkeğinde güçlü ve dayanıklı olması beklentisi mevcuttur.

Düğün günü gerçekleştirilen birçok ritüel ataerkilliğin, heteroseksüelliğin ve toplumsal cinsiyet eşitsizliğinin yaratılması ve pekiştirilmesine katkı sağlar. Batı kültüründe gelinin babasının veya başka bir erkek akrabasının kolunda nikah töreninin yapılacağı yere gelmesi ve damata teslim edilmesi söz konusu iken (Pepin et al. 2008), ülkemizde damat evinin, gelin evine gelerek gerçekleştirdiği gelin alma ritüeli vardır. Gelin alma sırasında baba, erkek kardeş veya ailenin erkeklerinden birisi dualar eşliğinde geline bekaretin sembolü olan kırmızı kuşağı bağlar ve damata teslim eder. Kırmızı kuşak bağlamak erkeğin kadının cinselliği üzerindeki kontrolünü sembolize ederken, ataerkilliğide destekler (Ingraham 1999). Her iki ritüel kadının bir erkekten başka bir erkeğin kontrolüne geçtiğini gösterir. Kadınların evlilik ilişkisine eşit bir temelde başlamadıklarının ve güçsüzlüklerinin sembolüdür (Besel et al. 2009). Hıristiyan çiftlerin kilise düğünlerinde geleneksel olarak söz verme töreni sırasında erkeklerin "karımı seveceğim ve onurlandıracă̆ım" derken kadınların "kocamı seveceğim, onurlandıracă̆ım ve itaat edeceğim" ifadesi de eşitsizliğin işaretidir (Fairchild 2014). Düğünün sonunda misafirler önünde gelinin bacağından jartiyerinin çıkartılıp erkeklere atılması (Fairchild 2014), damatın sırtına vurularak yatak odasına gönderilmesi, evlilik içinde cinsel birliktelik gerçekleştikten sonra silah atılması veya çarşafın başkalarına gösterilmesi gelinin cinsel olarak bir nesne olduğu mesajını vermektedir. Kına gecesinde gelinlerin, yöreye göre değişmekle beraber, bekar kızların boyunlarına şal veya tülbent takması, başlarına taç takması vd. gelenekler ve düğünde gelin çiceğini atmaları, heteroseksüel kadınların evlenme isteklerini ve evlenebilmek için yaptıkları rekabeti temsil eder. Kadın seçen değil seçilendir. Sayısız kadın içinden erkek onu sevmiş ve evlenerek onu onurlandırmıştır, bundan dolayı, diğer kadınlara göre talih kuşu başına konmuştur. Bu tür pratikler gelinin elde etmiş olduğu şansın bir başka kadına geçmesi düğüncesini taşırken tek eşliliğin ve heteroseksüelliğin normatif bir davranış olduğunu da yansıtır (Bambacas 2002; Pepin et al. 2008).

Hatta öyledir ki sadece kadınlar arası kutlama olarak düşünülen kına gecesi ve gelin partisi (bridal shower) gibi ritüellerde kadınlığı inşa ederken eşitsizliği tekrar yaratırlar. Kadın ve erkeklerin ayrıştı̆̆ kına gecesi ve gelin partisi ritüelleri kadınlıkla ilgilidir. Kına gecesinde kadının baba evini terk etmesinden bir gün önce gelin adayının feminenliğinin pekiştirildiği ve 
evlilik hayatına geçisinin kutlanması söz konusudur. Kına gecesine damat veya diğer erkekler katılmış olsalar bile burada merkezi konumda olan kadın ve kadınlar arasındaki ilişkidir. Batı toplumlarında yapılan gelin partisinde dügün öncesi gelin adayına kadınlar tarafından evinde kullanacağı ufak tefek hediyeler (çoğu zaman mutfak eşyası, havlu, nevresim takımları vd.) verilerek ev kadınlığı vurgulanırken, damat için düzenlenen bekarlığa veda gecesinde ise erkeğin cinsel olarak özgür geçirdiği son gece olarak erkekliği kutsanır. Gelin partisinde verilen hediyeler kadınların ev içinde karşılıksız emeklerini ve bakıcı rollerini pekiştirir ve feminenlikleri taçlandırılır. Başka bir ifade ile, kadına verilen hediyeler ev işlerinin kadının işi olduğu beklentisini pekiştirerek gelin adaylarından geleneksel kadın rollerini oynamaları beklenmektedir (Montemurro 2005). Kına gecesi veya gelin partisi gibi geceler yakında yapılacak olan dügünün gelin için ne kadar önemli olduğu ve eş olarak hazırlanması gerektiği anlamlarına sahip iken erkekler için yapılan kutlamalar ise evliliğin erkeği sınırladığı mesajını vermektedir. Bu tür geceler, kadınlığın ve erkekliğin etkileşimsel bir süreçte inşa edilmesine olanak sağlayarak toplumsal cinsiyet üyeliklerini sağlamlaştırarak eşitsizliği görünmez k1larlar (Montemurro 2005).

\section{Ev Kadınlığına Hazırlık: Düğün Hazırlığı}

Düğün öncesi birçok hazırlık erkekten daha çok kadının alanına girmektedir. Erkeğin maddi olarak eve alınacak eşyalarla ilgili destek vermesi gerekmekle beraber eşyaların seçimi ve evin hazırlanması hala kadının görevidir. Ülkemizde gelinlerin çeyiz getirmesi gelenekler arasında yer almaktadır. Anneler nerede ise kız çocukları doğduğu günden itibaren çeyiz hazırlamaya başlar. Çeyizin içinde büyük ev eşyalarından daha çok havlular, çarşaf ve nevresim takımları, danteller, aksesuarlar, mutfakla ilgili birçok araç gereç, patikler, yelekler, hatta ilerleyen zamanda doğacak olan çocuklar için bile giysiler bulunmaktadır. Evle ilgili gerekli olan birçok ufak tefek şeylerin hazırlığını gelin adayı ve ailedeki kadın akrabalar yapmaktadır. Oturma odasını seçmek için harcanan zamanla evde gündelik hayatta kullanılacak ufak tefek eșyaları hazırlamak için geçen zaman arasında önemli bir fark vardır. Düğün öncesi evle ilgili hazırlıklar, kadının alanın ev içi alan, temel sorumluğunun eş ve anne olduğunun göstergesidir. Bir çok evlilik sürecindeki ayrıntı ile de kadın ilgilenmektedir. Batı ülkelerinde yapılan araştırmalarda düğün planlama işinde gelin adaylarının daha çok emek sarf ettiğini ortaya çıkarmıştır. (Boden 2003; Otnes \& Pleck 2003). Dügün planlama, yemekleri hazırlama, dekorasyonu sağlama, gelenlerle ilgilenme, alışveriş yapma, temizlik yapma gibi ev işlerine benzer birçok işi gerektirdiği için yapılan işler görünmez hale gelmektedir. Dügünün planlanması kadınsı bir iş olarak görülmekte ve erkek daha çok bu işi kadına bırakmaktadır (Sniezek 2005). Erkekler bu sürece dahil olursa erkeksi işleri yapmaktadırlar (Humble et al. 2008). Bahsedildiği üzere, gelin partisi sırasında verilen hediyelerde kadının asıl yerinin ev içinde olduğunu erkeğin ise kamusal alan olduğunu vurgular. Düğün planlama hakkındaki birçok yayında erkeğin rolüne pek odaklanılmadığı ve gelinin planlama işinde merkezde olması gerektiği mesajı da verilmektedir. Hatta gelinlere özel ajandalar oluşturulduğunda düğün ajandası denilmek yerine gelin ajandası veya gelin günlügü adlarını verilerek dügün hazırlıklarının kadınların görevi olduğu mesaji sürekli verilmektedir (Bambacas 2002), çünkü kadınların, sanki kadın olmanın doğal bir uzantısı gibi dügünle ilgili hazırlıkları yaptıklarına inanılır (Humble et al. 2008). Bundan dolayı, düğün sürecinde ve düğünden sonra kadınının görünmeyen ve karşılığı ödenmeyen bir emeği mevcuttur (Sniezek 2005). Dügün sürecinde yapılan birçok hazırlık feminenlik, duygusallık ve tüketim gibi geleneksel kadın rolleri ve işleri ile ilişkilendirildiğinden bu işler kadınlara bırakılarak kadınların emeği bu süreçte bir kez daha karşılığını bulamaz (Blakely 2008; Besel et al. 2009). Kadının ev içindeki emeğinde olduğu gibi düğün sürecindeki emeği de sevgi, şevkat 
ve bağlılık ekseninde tanımlanarak harcanan zamanda ve çabadan bağımsız olarak değerlendirilerek, duygusal ilişkiler içinde görünmez kılınır. Tabii ki anneler kızları için ellerinden geleni yapacaktır, onların tek istediği kızlarının mutlu olmasıdır. Hep hayalini kurduğu düğün için kadınlar, bütün ayrıntılarla tek tek ilgileneceklerdir çünkü sevdiği erkekle en mutlu günüdür. Uykusuz geçen zamanlar, yapılan fedakarlıklar, çekilen sıkıntıların hepsi sevdikleri insanlar için yapıldığından emek karşılıksız kalmaktadır.

\section{Çiftin mi Gelinin mi Düğünü?}

Popüler söylem kadınların yaşantısında küçük kız olmaktan kadın olmaya geçtikleri en önemli aşamalardan birinin düğünleri olduğunu ileri sürer. Filmler, televizyon programları, edebiyat, aşk romanları, magazinler ve birçok kültürel unsur romantik aşk imgesi kullanarak düğünün kadınların hayatlarındaki en önemli gün olduğu mesajını verir. Kadınlar, küçüklükten itibaren düğün günün hayali ile yaşadıkları ve birgün o bekledikleri erkekleri bulup sonsuza kadar mutlu olacakları mesajı ile sürekli bombardıman edilmekle kalmayıp, hayatları boyunca bugün için yetiştirilirler. Kadınlar romantik aşk söylemi ile eğitilirek, eş ve anne olmanın onlar için herşeyden daha önemli olduğuna inandırılırlar (Ingraham 1999; Boden 2003). Aile, akran grupları, oyuncaklar, romanlar, magazinler gibi sosyalleşme sürecinde etkili olan öğeler, kız çocuklarına ve kadınlara ilişkilerin değerli olduğunu öğretir ve kadınlardan ilişkileri düzenleme konusunda başarılı olması beklenir. Aşk ve romantizm kadınların sorumluluğudur ve feminendir. Aile içi , akrabalar ve eşler arasındaki ilişkileri düzenlemek, onlar için çaba sarf etmek, sevgi göstermek, empati kurmak ve fedakarlık etmek hep kadının sorumluluğudur ve kadının alınıdır. Erkekler ise bütün bunların dışında kalanlardan sorumludur. Bu nedenle düğün ritüellerinin çoğunun kadınla ilgili olması ve düğünün kadının feminenliğini sergilemek için en büyük fırsat olması çokta şaşırtıcı değildir (Ingraham 1999; Otnes \& Pleck 2003). Evliliğin romantik aşk ile ilişkilendirilmesinden dolayı kadınlar çoğu zaman masalsı bir düğün hayal eder. Diğer kadınlar ile hayallerindeki düğünü paylaşırlar. Gidilen düğünler hemen iyi ve kötü yanları ile değerlendirilir, fotoğraf albümleri incelenir, evlilik teklifleri anlatılır ki kendi masalsı düğünlerinde hiç bir ayrıntı atlanmasın. Evlilik sürecinde olanlar, düğün planlarının ayrıntılarını diğer kadınlarla paylaşır ve dügün alışverişlerini de diğer kadınlarlar yapmaktan zevk duyar. Düğün hakkında konuşmak kadın dünyasının bir parçası haline gelmek ve kadın olmaktır. Bundan dolayı, kadınlar eğer nişanlı değil iseler, çıktıkları erkekler ile düğünler hakkında konuşmazlar. Çünkü evlilik delisi bir kadın olarak nitelendirilmekten sakınırlar (Arend 2016). Evlilik teklifini erkeğin yapması gerektiği ile ilgili normatif beklentilerden dolayı nişanlılık öncesi kadınlar erkeklerin yanında evlilik ve düğün konularından uzak dururlar.

Düğünün feminenliğin sembolü olarak kadınların en önemli günü olduğu söylemi kabul gördüğünden niçin düğünün çiftin değil de gelinin günü olduğu nerede ise sorgulanmaz. Gelinin düğünün merkezinde olması gerektiği düşüncesi çok doğal gelir. Damatlar bile bu söyleme inanırlar ve kendilerini düğünde ikincil olarak görürler. Damatlar için düğün günü pek de önemli değildir, ama o kadar kadın içinden seçip evlendikleri, kadının hayatındaki en önemli günü en özel hale getirmek için çaba sarf ederler (Humble et al. 2008; Fairchild 2014). Dügünlerde gelinlerin rollerinin damatlardan daha önemli olduğunun kabul edilmesi toplumsal cinsiyet eşitsizliği olarak görülmez, baskın toplumsal cinsiyet rollerinin doğal bir parçası olarak görülür (Fairchild 2014).

Özel alanın bir parçası olan düğünlerin kamusal alanda gerçekleşmesi ile eş, anne ve bakıcı olarak geleneksel toplumsal cinsiyet rolleri ile evin içine hapsedilmiş olan kadın bir anda kendini kamusal alanın merkezinde bulur. Gelinlerin kamusal alandaki görüntüleri baskın olan romantik aşk söylemi ile ilişkilendirilerek sevecen, aşkın sembolü, bakıcı ve ideal kadın imgesi 
yaratılır. Hayatlarında hiç odak noktası olmadıkları kadar kadınların düğün günlerinde merkezde olması, erkeklerin değil, kadınların geleneğin taşıyıcısı ve aktaracısı oldukları düşüncesini de pekiştirmektedir (Bambacas 2002). Dügün günlerinden kadınlara hiç olmadığı kadar değer verilirken geleneksel kadınlıkla ilgili normatif beklentilerde tekrar inşa edilmiş olmaktadır. $\mathrm{O}$ zaman düğünün merkezi olan kadın nasıl bir gelin imgesi yaratmalıdır?

\section{Hem Prenses hem de Süper Kadın, Gelinler}

İdeal gelinler, genç, zayıf, bakire, göz kamaştırıcı, cazibeli ama iffetli ve geleceğin annesi olarak dergilerde, magazinlerde ve romantik filmlerde sürekli resmedilirler (Boden 2003). Evliliğin temelinin romantik aşk olduğu söylemi etrafından yaratılan en baskın olan prenses gelin veya Sinderalla imgesi, gelinin düğün gününde nasıl olması gerektiği ile ilgili mesajları verirken masalsı ve romantik bir düğün miti ile toplumsal cinsiyet eşitsizliğini görünmez k1lar. Romantik aşk ve prenses gelin imgesinin en fazla öne çıktığı Grace Kelly'nin ve Leydi Diana'nın evlilik ve düğün törenleridir. Özellikle Leydi Diana'nın Prens Charles ile olan düğün töreni romantik aşkın görselleşmiş halidir. Leydi Diana, Sinderalle masalında olduğu gibi atların çektiği balkabağını andıran muhteşem bir araba ile kiliseye gelir. Gelinliği ve duvağı ise masallarda anlatılanlar gibidir (Ingraham 1999; Otnes \& Pleck 2003). Prenses gelin veya romantik gelin imgesi daha sonraki kraliyet ailesi, ünlülerin ve zenginlerin dügünlerinde de sıklıkla ön plana çıar. Örneğin, Kate Middleton ve Prens William'ın düğün töreni de bu imgeyi pekiştirir. Bu düğünlerden aklımızda kalanın daha çok gelinlerin güzellikleri ve giydikleri gelinlik olması hiç de şaşırtıcı değildir. Çünkü düğünün odak noktası damat değil gelindir. Diğer kadınlardan farklı olarak gelinler ne kadar feminen olduklarını gösterme firsatını elde eder. Gelinlerin feminenliklerini abartılı olarak sergilemeleri beklenir. Gelin sıradan olmamalı, bütün dikkatleri üzerine çekmeyi başarabilmelidir. Ancak bir prenses gibi göz kamaştırıcı olursa dikkatleri çekmekte başarılı olabilir (Boden 2003; Engstrom 2008). Feminenliğin mükemmel resmi gelinlerde hayat bulmaktadır. Hem kendisi hem de izleyiciler için görsel bir tahmine dönüşmelidir. Prenses gelin haline gelebilmek için gelinin yerine getirmesi gereken birçok kültürel zorunluluk vardır.

Mükemmel gelin imgesine ulaşmaya çalışan gelinlerin, düğün öncesi hazırlık sürecinde ve düğün gününde duygusal olmaları, sürecin tadını çıkarmaları ve săg duyularını kaybetmemeleri gerekmektedir. Bu süreçte hiçbir engel tanımadan istediğine ulaşmak isteyen gelinler kontrollerini kaybedebilir ve Gelinzilla'ya (Bridezilla) dönüşebilirler (Adrian 2006). Nasıl ki korku filmlerinde herşeyi elde etmek için kırıp, döken ve engelleri aşan Godzilla var ise, gelinler de dügün sürecinde duygularını ve davranışlarını kontrol edemeyerek canavarlaşabilirler ve kendilerini kaybedebilirler. Ancak ne kadar stresli, kaygılı, kendilerini baskı altında hissediyor olsalar bile başkalarının yanında kendilerine hakim olmayı başarmak zorundadırlar. Dügün hazırlık sürecinde kendi ailesi veya damadın ailesinden, akrabalardan, gelin birçok sıkıntı yaşayabilir. $\mathrm{Bu}$ sıkıntıları atlatmayı başararak kendi düğününün kahramanı olan, Boden'in (2003) tanımlaması ile "süper gelin" (superbride) olmalıdır. Evet duygularını göstermelidir fakat sinirli olmak, paniklemek, dehşet verici hissetmek gibi kadınsı olmayan duyguları kontrol altına almalı, davranışları sınırlamalı ve kontrolünü kaybetmiş bir gelin resmi çizmemelidir. Örneğin, Sinderella görüntüsünü yaratacağını düşünerek gelinlik seçen fakat dügün günü omuzlarının Sinderalla'nın omuzları gibi ince zarif olmadığını ve gelinliğin kendine hiç yakışmadığına düşünüp ağlamaya başlayan ve etraftaki herşeyi kırıp döken ve sızlayan bir gelin kontrolü kaybetmiştir. Gelinin tekrar kendini toparlaması için bir erkeğin, ne kadar güzel olduğuna, gelinliğin mükemmel göründüğüne, düğün stresinden dolayı böyle hissettiğine gelini inandırması gerekmiştir (Boden 2003). Duygularını ve davranışlarını kontrol ettiği zaman narin, kırılgan, romantik ve zarif prenses gelin olmayı başarabilir. Bunları başaramaz ise, feminenlikle ilgili normatif beklentileri 
karşılayamadığı için anormal olarak görülecek ve canavarlaştırılacak, bencil olarak tanımlanacaktır. Duyguları ve davranışları ile beraber düğün sürecinde kontrolün kendinde olduğunu göstermesi gerekir. Planlamaları ve düzenlemeleri yapmalıdır. Hayatının en özel gününü en ince ayrıntıya kadar kontrol altında tutma becerisine sahip olmalıdır (Boden 2003; Engstrom 2008). Bir gelinin nasıl davranması ve düğünün nasıl kontrol altında tutması gerektiği ile ilgili beklentiler farklı aktörler tarafından öğretilir. Örneğin, gelinlik mağazalarında çalışanlar kendilerini düğün ritüelleri konusunda uzman kabul ettikleri için gelinlerin mağaza içi ve dışından mükemmel bir gelin olması için yapması gerekenler hakkında uzman gözü ile gelinleri eğitirler. Dügün gününün gelinin günü olduğu ve herşeyin gelinin istediği gibi olması gerektiği ve gelinin kontrolü eline alarak yolunda gitmeyen işleri düzeltmesi gerektiği öğütlenir. Eğer gelin kontrolü kaybeder ise, hayatındaki en güzel gün rezil olacaktır. Gelinin asla buna izin vermemesi gerekir (Corrado 2002). Gelinlerin gelinzilla değil süper gelin olması beklenmektedir.

\section{Feminenliğin Sembolü Gelinlik}

Düğünle ilgili en önemli sembollerden birisi gelinliktir. Kadının feminenliğini göstermek için en önemli nesne olan gelinlik hiç bir elbisede olmayan bir güce sahiptir. Gelinlik bir kadını sıradan bir kadın olmaktan gelin olmaya dönüştürme gücüne sahiptir. Düğünde gelinden daha çok gelinlik gösterinin yıldızı olmaktadır. Beyaz gelinlik giymek artık norm halini almıştır. Kraliçe Victoria dönemine kadar kadınların düğünlerde beyaz gelinlik giyme geleneği yoktu. Kraliçe Victoria kendi düğününde oldukça güzel beyaz bir gelinlik giyer ve orta sınıf kadınlar onu takip etmeye başlar. Yirminci yüzyılın başında batı ülkelerinden beyaz gelinlik giymek bir norm olur (Ingraham 1999). Beyaz gelinlik romantik aşkın ve duyguların sembolü haline geldiği gibi, gelinliğe birçok anlam yüklenerek toplumsal olarak cinsiyetlendirilmiş düzenin devamını sağlayan norm ve değerler gizlenir ve bulanıklaştırılır. Gelinlik kadınların toplumsal normlara uygun davranmasını sağlayarak sosyal kontrol mekanizması görevini görür. Ancak, normlara uygun davranmış olan kadınlar gelinlik giymeyi hak ederler. Gelinlik, masumiyeti, saflı̆̆1, temizliği, iffeti, cinsel olarak dokunulmamış olmayı temsil eder. Kaçarak evlenen, hamile kalan veya ikinci kez evlenenlerin normlardan saptıkları için gelinlik giymeleri pek de onaylanan bir davranış değildir. Tarihsel olarak kadınların evlilik öncesi bakire olması bir normdur ve bu norm hala birçok ülkede güçlü bir şekilde varlığını devam ettirmektedir, hatta bu normdan sapan kadınların öldürüldüğü veya şiddete maruz kaldıklarını da biliyoruz. Birçok toplumda gelinin bakire olması ile ilgili bir baskı mevcut iken erkekler için böyle bir baskı söz konusu değildir. Heteronormatif düzen kadının cinselliğini kontrol altına alır ve evlilik ile ilişkilendirirken erkeklerin cinselliğini özgürce yaşaması ise maskulen olmanın bir göstergesi olarak kabul eder. Birçok ülkede erkeklerin damatlığ olarak saf kalarak gelinliği hak etmesi gerekir.

Günümüzde Batı ülkelerinde beyaz gelinlik bekaretten daha çok feminenliğin sembolü olarak görülmektedir. Uzun süre birlikte yaşadıktan, çocuk sahibi olduktan sonra evlenen kadınların veya hamile gelinlerin feminenliğini göstermesinin temel yolu düğünde gelinlik giymesidir. Dügün kadınlar için romantik aşkı ve fantazi dünyasını temsil ettiği için bakire olmayan kadınlar da bu fantazinin bir parçası olmak isterler. Gelinlik giyerek dügünde ne kadar feminen olduklarını herkese kanıtlama arzusundadırlar (Nash 2013).

Gelinin mükemmel feminenliğini göstermesi için zorunlu bir öğe olan gelinliğin seçimi de oldukça önemlidir. Çünkü gelinden daha çok gelinlik gösterinin merkezinde yer alacaktır. İstenilen prenses görüntüsünü yakalamak hiç de kolay değildir. Gelinler sadece güzel bir gelinliği bulmak için değil, kendileri için "doğru gelinliği” bulmak için yoğun çaba harcarlar. "Doğru gelinliği" giymek için uygun kültürel ve bedensel sermayeye sahip olmaları gerek- 
mektedir. Beden bireyin benliğini de yansıttığı için gelinliğin gelinin benliğine de uygun olması, benliğini yansıtması beklenir. Gelinliğin "doğru gelinlik" olması gelinliğe yüklenen tarihsel anlamlarla ilgilidir. Batı kültüründe saygınlık, üst ve orta sınıf kadınlarla ilişkilendirilir. Üst ve orta sınıf kadınlar göz kamaştırıcı ve cazibeli ama aynı zamanda iffetli ve ahlaklı olarak tanımlanırken, işçi sınıfı kadınları agresif, cinselliklerini istedikleri gibi yaşayan, oldukça erkeksi olarak tanımlanırlar. Bundan dolayı, gelinlik gelinin kim olduğunu da yansıtmalı. Abartısız, rahat, iffetli ama bir o kadar göz alıcı ve cazibeli bir görüntüye sahip olmak için gelinlerin çok çabalamaları gerekmektedir (Broekhuizen \& Evans 2016).

Damatlık seçmek bir kaç hafta içinde yapılabilecek iken gelinlik seçmek uzun ve meşakatli bir iştir, o kadar özel bir elbise aceleye getirilemez. En az 6 ay belki daha öncesinden gelinlik bakma sürecine başlanmalıdır ki, hayallerdeki gelinlik bulunabilsin (Corrado 2002). Gelinlik seçmek, gelinin düğünle ilgili alabileceği en önemli karar olduğu için genellikle bu kararı tek başına alması istenmez ve destek olarak aile üyeleri veya arkadaşlar da gelinin yanında olurlar. Medya, evlilik, düğün ve gelin dergileri prenses gibi bir gelin olmak için nasıl bir gelinlik seçilmesi gerektiği konusunda da sürekli mesajlar vermektedir. Engstrom (2008) düğün programlarını incelediği makalesinde prenses gelin imgesinin baskın olduğunu gösterir ve gelinlerinde en fazla "prenses gibi hissediyorum" cümlesini ve eşlik edenlerin de, özellikle annelerin, gelinlere "ne kadar güzel oldun" cümlesini sıklıkla kullandıklarını belirtir. Örneğin, başka ülkelerde yayınlandığı gibi ülkemizde de TLC kanalında yayınlanan ünlü bir moda evinde geçen "Say Yes to the Dress" (Gelinliğe Evet De) programında, gelinler hayallerindeki gelinliği bulma umudu ile bu moda evine, özellikle anneleri, büyük anneleri ve kız arkadaşları ile beraber gelirler. Bazen baba, büyük baba veya erkek kardeş de bu grubu katıldığında gelinin babasının küçük prensesi olduğu algısı pekiştirilir. Gelinlik ne kadar pahalı bile olsa eğer genç kadın beğendi ise babası küçük prensesinin kalbini kırmaz ve gelinliği alır. Profesyonel danışmanlar eşliğinde hayallerdeki gelinlik bulunmaya çalışılır. Gelin bu süreçte birçok gelinlik dener ama bir tanesi hepsinden çok farklıdır. Herhangi bir gelinlik değil, "doğru gelinlik” gelinde duygusal bir patlama yaşatır. İşte o gelinliği giydiğinde, gelin göz yaşlarını tutamaz ve nefesi kesilir, tarif edilemez duygular içinde olduğunu ifade eder. Geline eşlik edenler de göz yaşlarını tutamayarak gelinliği onaylar. Engstrom'un (2008) araştırmasında olduğu gibi, çoğu zaman, gelinler kendilerini prenses gibi hissettiklerini ve rüyalarındaki gelinliği bulduklarını belirtirler. "Doğru gelinliği" bulmak uzun bir süreçtir. Programda tabi ki ünlü moda evine gelip hayallerindeki gelinliği bulamayan gelinler de mevcuttur. Mükemmel gelinliği saran sihiri hissetmek gelinler için o kadar önemlidir ki, gelinler bu sihiri buluncaya kadar aramayı bırakmazlar, gerekirse bir tasarımcı ile anlaşarak hayallerindeki gelinliği hayata geçirirler (Engstrom 2008). "Doğru gelinliği" bulmak paha biçelemez bir değere sahiptir.

"Doğru gelinliği”" bulmakla, gelinler için süreç tamamlanmıyor, damatların, damatlık konusunda eğitilmesi gerekmez iken gelinlerin gelinlik konusunda eğitilmeleri gerekir. Gelinlerin gelinliği nasıl sipariş vermesi, nasıl giymesi, bedenlerini gelinliğe uygun hale nasıl getirmeleri gerektiği, hangi aksesuarları takmaları gerektiği konusunda da eğitilmesi gerekir. "Doğru gelinlik" bulunmuş olabilir ama dügünden 3 hafta önce gelinlik bulundu ise gelinin istediği mükemmel görüntüye ulaşması pek mümkün değildir, çünkü gelinlik aceleye getirilerek dikilecek bir elbise değildir. Sihir gibi kadını dönüştürme gücüne sahip olan gelinliğin dikimi için en az 6 ay gerekir ve gelinin 4-5 kere provaya gitmesi beklenir. Fakat bu süreçte gelinin dikkat etmesi gereken öğeler vardır. Kilo kaybedebilir fakat gelin kesinlikle kilo almamalı ve hamile kalmamalıdır. Şişman veya hamile bir gelinin istenilen ideal feminen görüntüyü yakalaması zordur. Gelinlere aynı beden büyüklügünde kalmaları için sözleşme imzalatılır (Corrado 2002). Gelinlerin bedenleri üzerindeki baskıdan dolayı güzel gelin imgesinden uzak bir bedene 
sahip olan gelinler "doğru gelinliği” aramaktan çok kendilerini fil veya balon gibi göstermeyecek normal bir gelinlik aramaktadırlar. Düğün günlerinde normal bir gelin olma arzuları ile feminenliklerini sergilemek isterler (Broekhuizen \& Evans 2016).

Gelinlik diğer elbiselerden o kadar farklıdır ki, tek başına gelinin giymesi bile mümkün değildir, ancak başkalarından yardım alarak giyebilir (Engstrom 2008). Gelinlerin gelinliği giyme üzerinde taşıma hatta evde düğüne kadar nasıl saklayacakları konusunda da eğitilmeleri gerekmektedir. Tarlatanın doğru şekilde giyilmesi, eteklerin düzeltilmesi, duvağın en güzel şekilde konumlanması ve yere kadar uzanıyor ise ona göre şekillenlendirilmesi sihirli bir görüntüye ulaşmak için gereklidir. Hatta, gelinliğin mağazadan eve getirilip düğün gününe kadar evde nasıl tutulması ve tehlikelerden nasıl korunması gerektiği bile geline öğretilir. Gelinlik evde güvenli bir odada durmalı, asla elbise dolabına asılmamalı, tavandan yere doğru odanın ortasında asılı durmalı, gelin dahil kimse denememeli ve dokunmamalıdır. Mükemmel gün için gelinlik kırışmamalı ve kirlenmemelidir. Eğer bunlara dikkat edilmez ise gelinin prenses görüntüsüne ulaşma çabası boşa gitmiş olacaktır (Corrado 2002).

Gelinliğin tamamlayıcı öğeleri olan saç ve makyaj feminen kimliğin tasdik edilmesi ve sağlamlaştırılması için gereklidir (Boden 2003; Engstrom 2008). Damadın damatlığı giymesi, saç ve sakal traşı olmasına harcadığı zaman ile gelinin saç ve makyaj yaptırmaya harcadığı zaman arasında büyük bir farklılık vardır. Hatta, artık çoğu gelin, düğün öncesinde saç ve makyaj provası yaparak düğün gününde mükemmel bir görüntüye sahip olmayı garanti altına almaya çalışır. Geline uygulanan makyaj artık sıradan bir davete giderken yapılandan çok farklıdır, çok dikkatlice ve özenle profesyoneller tarafından yapılmalıdır. Hatta gelinler saç ve makyaj yapılırken video görüntüleri kaydederek veya fotoğraf çekerek dönüşüm sürecini ölümsüzleştirirler. Gelinlikle beraber saç ve makyaj ile oluşturulan görüntü feminenliğin görsel halidir. Evlenecek olan kadın artık gerçek bir geline dönüşmüştür, tabi ideal beden ölçülerine sahip ise.

İdeal feminenliği yakalamak için ödenmesi gereken "küçük" bedeller vardır. Gelinliğin içine giyilen korseler, bedeni çok sıktıkları için gelinlerin acı çekmelerine yol açar. Vücutlarında kızarıklıklar oluşsa veya ağrı hissetseler bile güzel göründükleri sürece $22 \mathrm{~kg}$ ağırlığında bir gelinliği taşımak gelinlerin gözünde pek de sorun değildir (Corrado 2002; Broekhuizen \& Evans 2016). Saçları yapılırken feminenliklerini ortaya çıkarmak prenses görüntüsünü yakalamak için bütün saçları köklerinden çıkıyormuş gibi acı hissetseler veya çok sıkı olduğu için takılan tokalar canlarını yaksa da güzel olmak acı çekmeye üstün gelmektedir (Engstrom 2008). Dügün gününde rahatsız olunuyor diye korse giymeyip göbeğin görünmesinden veya tokalar saç derisini açıtmasın diye bir kaç saat içinde dağılabilecek bir saç modeli kullanıp özensiz bir gelin imgesi oluşturmaktansa, acı çekip güzel olmak çok daha önemlidir. Hayatlarındaki en önemli günde herkesden daha feminen olmak için çekilen acılar ve rahatsılılılar küçük bir bedeldir.

\section{Mükemelliğin Resmi Gelin Bedeni}

Düğünde gelinin sergilediği feminenliğin izleyiciler tarafından onaylanması, gelinin kültürel normlara uygun olarak başarılı bir gelin olduğu anlamına gelir (Boden 2003). Prenses gelin imgesine ulaşmak için, gelinin bedeninin bu imgeye uygun hale getirilmesi gerekmektedir. Damatların bedenleri üzerinde baskı hissedilmez iken mükemmel feminenliğin resminin çizildiği düğün günü için gelinin bedeni tekrar inşa edilmelidir (Nash 2013). Kadın bedeninin kontrol altına alınması ve nesneleştirilmesi tarihsel sürecin bir sonucudur. Günümüzde yasaklanmış olsa da, tarihsel olarak Çin'de yüksek sınıftan Çinliler arasında kadınların ayaklarının küçük görünmesi için sargılanması ve küçük ayakların erkeklerin arzu nesnesi haline gelmesi, bazı Afrika 
ülkelerinde hala kadın sünnetinin yaygın olması, gibi birçok gelenek ile kadınların bedenleri sürekli inşa edilmiş ve arzu nesnesine dönüşmüştür. Günümüzde gençlik ve kadın dergileri, magazinler, hayat tarzı dergileri gibi birçok dergi, kitap ve program kadınların ince ve zayıf bir bedene sahip olması gerektiği mesajını sürekli vermektedir. Beni baştan yarat formatındaki birçok programda önce kadınların kilolarından kurtulmaları sağlanır sonrada güzelleşmeleri adına vücutlarına birçok uygulama gerçekleştirilir. Güzel kadın sağlıklı bir bedene sahip olmaktan daha çok hakim söylemin istediği bakımlı bir bedene ve görüntüye sahip olmalıdır. "Çirkin kadın yoktur bakımsız kadın vardır" ifadesi kadınların güzel görünmek için ellerinden gelini yapması gerektiği mesajını veriyor. Güzel olmaktan daha çok güzel görünmek önemli hale geldiği için güzel görünmek için kadınlar çaba sarf etmiyor ise bu onların kendi suçudur. Çünkü güzel görünmek için bütün firsatlar kadınlara sunulmaktadır. Güzel görünmeyi kadın kendisi başaramıyor ise diyetisyeni, estetik uzmanı, güzellik uzmanı, spor eğitmeni gibi uzman kadrolar kadının istediği görüntüye ulaşması için yardıma hazırdır. Araştırmaların sonuçları bu baskıya karşı kadınların kendi görüntülerinden hiç de memnun olmadıklarını ortaya koymaktadır. Örneğin 10 farklı ülkede 18-64 yaş arasındaki 3200 kadın katılımcı ile yapılan Dove firmasının "The Real Truth About Beauty: A Global Report 2004" (Güzellik Hakkında Gerçekler: Küresel Rapor 2004) araştırmasına göre, kadınların sadece \%2'si güzel, \%9'u çekici, \%8'i feminen olarak kendilerini tanımlamıştır. İlginç olan 18-29 yaş arasındaki genç kadınlarında sadece \%4'ü kendisini güzel bulmaktadır. Kadınların \%32'si doğal ve \%25'i ise ortalama bir görüntüye sahip olduklarına inanmaktadırlar ve çoğunluğu kendilerini güzel olarak tanımlama konusunda rahat hissetmemektedirler. Kendi güzelliklerini başka kadınlarla karşılaştırdıklarında, kadınların \%72'si kendisini ortalama olarak görmektedir. Yarıya yakını kilolarının yüksek olduğuna inanmaktadırlar. Biri onlara aşık olduğunda, evlendiklerinde veya ciddi bir ilişki içinde olduklarında kendilerini güzel hissetmektedirler. Kadınların çoğunluğu fiziksel olarak çekici hissetmek için saç ürünleri, parfüm, cilt bakım ürünleri, makyaj ve kozmetik ürünleri, el bakım ürünlerini sıklıkla kullanmaktadırlar. Her dört kadından biri daha çekici olmak için estetik ameliyat yaptırmayı düşünmektedir (Etfoff \& Orbach 2004). Bir önceki araştırmanın devam niteliğinde olan “The Dove Global Beauty and Confidence Report 2016”da (Dove Küresel Güzellik ve Kendine Güven Raporu 2016 (PRNewswire 2016)) kadınların bedenlerine olan güvenlerinin giderek azaldığ 1 ve görünüşlerinden memnun olmayan her on kadından dokuzunun yemeği bırakacağı tespit edildi. Medyanın kendileri için ulaşılmaz bir güzellik standardı oluşturduğuna inanmaktadırlar. Kadınların sağlıklı olmaktan daha çok güzel ve bakımlı görünmeleri için üzerlerindeki baskı giderek artmaktadır. Bir çok genç kız bu baskıya dayanamayıp ideal olarak gösterilen modellerin, mankenlerin, film yıldızlarının görüntülerine sahip olmak için anoreksiya tehlikesi ile karşı karşıyadır. Hele ki bu kadınlar düğün hazırlığı içinde iseler, gelin adayı üzerindeki baskı daha fazladır, çünkü gelinlerin bedenleri mükemmelliğin taşıyıcısıdır. Gelinliğin içinde kadınlar prensesler gibi zarif olmalı ve etrafa 1şıltı yaymalıdır. Bundan dolayı, gelinlerin bedenleri çeşitli yöntemler ile hayatlarındaki en önemli ve özel güne hazırlanmalıdır. Başarılı bir düğün ancak fit bir beden ile gerçekleşebilir. Gelinlere özel diyet kitapları, diyet programları, fitnes programları gelinin ideal gelin bedenine nasıl ulaşabileceği konusunda yol haritasını çizer (Winch \& Webster 2012). Popüler kültür ürünlerinin yanı sıra, gündelik hayatlarında gelin adaylarına kilo vermesi gerektiğini söyleyenler arasında gelinin annesi, nişanlısı, arkadaşları ve gelinlik mağazasında çalışan elemanlar yer almaktadır. Kiloları yüksek olan gelin adayları birden fazla kişiden kilo kaybetmesi gerektiğini duymaktadır (Prichard \& Tiggeman 2009). Baskıya dayanamayan gelin adayları, düğün öncesinde kilo kaybetmeyi veya en azından kilo almamayı planlamaktadırlar. Araştırma bulguları gelinlerin düğün öncesi istedikleri kiloya ulaşamasalar bile kilo verdiklerini tespit etmiştir (Neighbors \& 
Sobal 2008; Prichard \& Tiggeman 2008; 2009). Kilo kaybetmek için kadınlar sağlıklı ve sağlıklı olmayan radikal birçok stratejiler kullanmayı planlamaktadırlar. Kadınlar fazla su içmeyi, aerobik yapmayı, daha çok egzersize yapmayı, spor salonuna gitmeyi, sağlıklı yeme planı uygulamayı, diyetlerinde yağ veya karbonhidrat oranını azaltmayı, daha az yemek gibi farklı teknikleri kullanmayı tasarlamaktadırlar (Neighbors \& Sobel 2008; Prichard \& Tiggeman 2008; 2009). Öğün atlama, reçeteli veya reçetesiz diyet ilaçları kullanma, oruç tutma, bağırsak düzenleyici ilaç kullanma gibi daha radikal tekniklerde kullanılmaktadır. Hatta, kilo kaybetmeyi kesinleştirmek için dügünden uzun bir süre önce bir beden küçük gelinlik alanlar bile vardır (Neighbors \& Sobel 2008). Damatların ve gelinlerin kiloları karşılaştırıldığında kilo kaybeden gelinlerin damatlarla benzer bir kiloya sahip oldukları, kilo kaybetmeyen gelinlerin ise damatlardan daha ufak tefek oldukları bulunmuştur (Prichard et al. 2015). Hatta gelinler sağlıklarını riske atacak şekilde anoreksik davranışlar gösterdikleri için gelin-anoreksiyası (bride-orexia) terimi kullanılmaya başlanmıştır (Prichard \& Tiggeman 2008).

Gelinin sadece kilo kaybetmesi yeterli değildir, aynı zamanda fit bir bedene de sahip olmalıdır. Bu uğurda gelinleri istenilen ideal bedene ulaştırmak için fitnes programları vardır. Askeri bir disipline sahip olan gelin kampları mevcuttur. Örneğin, Bridal Boot Camp, 2001 yılında ünlülerin bireysel spor eğitmeni olan Cynthia Conde tarafından New York'da kurulmuştur. Bu kampta 10 haftalık kişiselleştirilmiş bir program uygulanmaktadır (Winch \& Webster 2012). Askeri disipline sahip gelinlere yönelik bu programların sayısı oldukça fazladır. Chicago'da yer alan Wedding Boot Camp programı (WBC Wedding Boot Camp) 45-55 dakika süren dersler ile düğün gününe kadar bir ayda en az bir beden zayıflatmayı garanti etmektedir. Brides (Gelinler) sayfası ise gelinlere en iyi 12 zayıflama kampını belirleyerek yol göstermektedir (BRIDES The Best Bridal Boot Camps 2012). Gelinlerin ev ortamında benzer bir program1 uygulamaları için birçok kitap (Neighbors \& Sabol 2008) ve internette birçok dergi ve program bulunmaktadır. Örneğin, online yayın yapan Fittnes magazin, gelinlere özel Bridal Boot Camp: The Workout adındaki programı ile gelinlerin ev ortamında nasıl kilo kaybedip seksi bir bedene sahip olabileceklerini anlatmaktadır. Gelinlerin takip etmesi gereken hareketler açıklandığı gibi gelinler isterler ise programın videosunu da satın alabileceklerdir. Program evlilik sürecinde birçok kadının kilolarından kurtulmasına yardım eden ünlü bir spor eğitmeni tarafından hazırlanmıştır. Harper Bazaar gibi popüler dergilerde benzer programlara yer vererek gelinlerin fit bir bedene sahip olması gerektiği mesajını vermektedirler (Hopkins 2014). Damatlar için kamplar olup olmadığını online olarak sorguladığımızda, damata özel olmaktan daha çok damat ve gelin için beraber düzenlenen programlar olduğunu görülmektedir (Northwest Crossfit Offers Bride \& Groom Boot Camps).

Prenses görüntüsüne sahip olmak için kilo kaybetmek ve fit bir bedene sahip olmak yeterli değildir. Gelinlerin prenses görüntüsünü bozacak anormalliklerden kurtulmaları gerekmektedir (Boden 2003; Nash 2013). Birçok dergi ve kitap gelinlerin bu özel güne bakımsız ellerle gidemeyeceği, maskeler ile yüzlerindeki çizgileri ve siyah noktaları yok etmeleri, güzel kokmaları, düğün gecesi seksi olmak için çekici iç çamaşırları giymeleri gerektiği yönünde mesajlar vermektedirler (Boden 2003). Bunlarla birlikte, gelinlerin güzelliklerini tamamlayacı bir gülüşe sahip olması gerekir. "Here comes to bride.. and her teeth are nice and bright!" ( İște gelin geliyor.. ve dişleri güzel ve parlak) başlıklı yazı 2004 yılında Amerikan Diş Hekimliği Derneği Dergisi'nde (JADA 2004) yer alarak gelinlere mükemmel gülüşe nasıl sahip olabileceklerini anlatıyor. Düğün öncesinde dişler beyazlatılmalı, dişlerde bozukluklar varsa giderilmeli, hatta gerekiyor ise baştan tekrar yaptırılmalıdır. Bu mesajların baskısını hisseden gelin adaylarının çoğunluğu dügün öncesinde dişlerini beyazlatmayı, bronzlaşmayı, cilt renglerini açtırmayı, yüz, cilt bakımı ve masaj yaptırmayı, sıkılaştırıcı ürünler kullanmayı, 
epilasyon yaptırmayı, gerekirse gögüslerini düzelttirmeyi ve botoks yaptırmayı planlamaktadırlar (Prichard \& Tiggeman 2008; 2009). Bunları yaptırdıklarında hayatlarının en güzel ve önemli olan gününde mükemmel feminenliğin resmini çizmiş olacaklardır.

Gelinler güzel ve fit bir bedene sahip olmayı ve düğünlerinde güzel görünmeyi istemelerinin nedenleri arasında en fazla düğün fotoğrafları gelmektedir. Bu fotoğraflar gelinlerin güzelliklerini ve göz alıcı bedenlerini ölümsüzleştireceği ve hayatların geri kalan kısmında fotoğraflara bakıp o günü hatırlayacakları için fotoğraflarda çirkin ve şişman görünmek istemezler. Dügün günü hayatlarındaki en özel gün olduğu ve bütün gözler onların üzerinde olacağı içinde güzel görünmek için gereken herşey yapılmalıdır (Prichard \& Tiggeman 2008). Yapılan herşey birgün bile olsa güzel görünmek ve bütün bakışları üzerine çekmek için ödenen küçük bir bedelden başka birşey değildir. Gelin bedeninde kadın bedeni bir kez daha arzu nesnesi halini almıştır.

\section{Tartışma}

Toplumsal cinsiyetlendirilmiş olduğunu hissettirmeden, toplumsal ritüeller baskın olan normatif sistemi aktarır ve yeniden yaratır. Ritüeller ataerkilliğin, heteroseksüelliğin ve toplumsal cinsiyetin taşıyıcısıdırlar. Dügün ritüelleri bir fantazi dünyası yaratarak, kadın ve erkek olmanın anlamı ve aralarındaki ilişkinin nasıl olması gerektiği hakkında mesajlar vererek toplumsal cinsiyetin performans aracıllı̆ı ile tekrar yaratılmasını sağlar (Fairchild 2014). Düğün ritüelleri bağlamında gerçekleştirilen etkileşimler tarihsel olarak toplumsal cinsiyet etrafından yaratılan eşitsizlikten bağımsız değildir. Bireyler kendi istedikleri gibi özgürce ritüelleri gerçekleştirdiklerini düşünseler bile ritüellerin içine gömülü olan eşitsizliği fark etmeksizin yaratmaktadırlar. Davul ve Zurna ile kadının bir erkeğin kontrolünden başka bir erkeğin kontrolüne geçiş süreci o kadar doğal geliyor ki diğer türlüsünü sorgulamak aklımıza bile gelmiyor. Aşk ve sevgi adına gelin adayı, evle ilgili bütün hazırlıkları yaparken, evini tam olarak hayalindeki gibi bir yuva olarak dekore etmeye çalışırken ev içi alanın-özel alanın kadına ait olduğu ve geleneksel kadın imgesini pekiştirdiğinin hiç de farkında değildir. Gelin, düğünde ne kadar feminen olduğunu göstermeye çalışırken üzerindeki baskıları sorgulama firsatı elde etmeden eşitsizliği tekrar yaratıyor. Fakat birçok çifte sorulsa kendi düğünlerinde herhangi bir eşitsizliğin olmadığını, herkesin elinden gelen herşeyi yaptığını ve sorumluğu eşit paylaştıklarını anlatarak kendi düğünlerini ayrı tutacaklardır. Birçok şeyi yapmaya kimsenin onları zorlamadığı ve kendi istedikleri için yaptıklarını büyük bir olasılıkla vurgulayacaklardır. Doğal görünen bu süreç eşitsizliği tekrar inşa ediyor. Evlililiğin temelinin romantik aşk olduğu söylemi heteroseksüelliği ve toplumsal cinsiyet eşitsizliğini bir fantazi ve masal dünyasına dönüştürerek görünmez kılar (Ingraham 1999). Kızlar küçük yaştan itibaren beyaz atlı prenslerinin gelip onları kurtarmalarını beklerler. Birgün prensler onları evlerinin kadını yaparak baş taçı edecek ve sonsuza kadar mutlu yaşayacaklardır.

Çok doğalmış gibi gelen ritüeller norm dışı davranıldığında sorgulanmaya başlanıyor. Ne zaman ki bir kadın bir erkeğe evlilik teklifi yaptığında, hamile bir kadın gelinlik giydiğinde veya engelli bir kadın feminenliğini sergilemek istediğinde, iki kadın veya iki erkek evlenmek istediğinde doğal gibi gelen ritüeller üzerindeki örtü kalkmaya başlıyor. Elli yaşlarında bir kadın, kendinden 20 yaş küçük bir erkek ile gelinlik giyip, düğün yaparak evlenmek istediğinde nasıl tepkilerle karşılaşır? Elli yaşında bir kadının gelinlik giymeye hakkı var mıdır? Tekerlekli sandalyede hayatını geçirmek zorunda olan genç bir kız aynı yaşta fiziksel engeli olmayan bir erkek ile evlenebilir mi? Okuyucuların bazıları tabi ki evlenebilir önlerinde herhangi bir engel yok ki, sevdiler ise neden olmasın diye sorulara yanıt verebilir. Aşk herşeye kadir ise eşcinsel evlilikler niçin kabul görmemektedir? Yaratılan gelin imgesine baktığımızda heteroseksüel, genç, sağlıklı, herhangi bir fiziki engeli olmayan, ince ve zarif bir kadındır. Elli yaşındaki 
kadının sarkık kolları prenses gelinliğin içinde beklenen görüntüyü sağlayabilecek midir? Uzun, ince ve zarif olarak kurgulanan gelin imgesi tekerlekli sandalyedeki gelinde hayat bulabilecek midir? Obez gelinler, boyları kısa veya çok uzun gelinler, gelinlik içinde ideal feminenliğin yansıması olabilecekler midir?

Düğünle ilgili ritüeller kadının feminenliğini sergilmesi için bir firsattır. Baskın toplumsal düzen romantik aşk, prenses gelin ve kurtarıcı erkek söylemleri etrafından feminenliği yaratarak kadının duygularını, davranışlarını, bedenini ve emeğini kontrol altına almaktadır. Romantik aşk söylemi etrafından oluşturulan fantazi dünyası kadının ataerkil toplumsal düzene itaat etmesini sağlayarak eşitsizliği yaratmaktadır. Kadın normatif beklentileri karşıladığı sürece ataerkil sistem tarafından eş ve kutsal anne olarak ödüllendirilecektir. Kadınlar düğün sürecinde kısa süreliğine fantazi dünyasının bir parçası olduktan sonra hiç çıkmadıkları asıl alanları olan evin içine geri döneceklerdir. Aslında ataerkil sistem kısa süreliğine de olsa kadınları odak noktası yaparak onlara lütfetmiştir. En sonunda herkes toplumsal düzende yerini almalıdır.

\section{KAYNAKÇA}

Acker J. (1992). “From Sex Roles to Gendered Institutions”. Contemporary Sociology 21/5 (1992) 565-569.

Adrian B. (2006). "Bridezilla Consciousness”. Journal of Women's History 18/4 (2006) 108-113.

Arend P. (2016). "Consumption as Comman Sense: Heteronormative Hegemony and White Wedding Desire”. Journal of Consumer Culture 16/1 (2016) 144-163.

Bambacas C. (2002). "Thinking about White Weddings”. Journal of Australian Studies 26/72 (2002) 191-200.

Besel A., Zimmerman T. S., Fruhauf C. A., Pepin J. \& Banning J. H. (2009). "Here Comes the Bride: An Ethnographic Content Analysis of Bridal Books”. Journal of Feminist Family Therapy 21/2 (2009) 98-124.

Blakely K. (2008). "Busy Brides and the Businnes of Family Life, the Wedding Planing Industry and the Commodity Frontier”. Journal of Family Issues 29/5 (2008) 639-662.

Boden S. (2003). Consumerism, Romance and the Wedding Experience. New York 2003.

Broekhuizan F. \& Evans A. (2016). "Pain, Pleasure and Bridal Beauty: Mapping Postfeminist Bridal Perfection”. Journal of Gender Studies 25/3 (2016) 335-348.

Connell R.W. (1987). Gender and Power: Society, the Person and Sexual Politics. Palo Alto 1987.

Corrado M. (2002). "Teaching Wedding Rules: How Bridal Workers Negotiate Control over their Customers”. Journal of Contemporary Enthography 31/1 (2002) 33-67.

Engstrom E. (2008). "Unravleing the Knot: Political Economy and Culturel Hegemony in Wedding Media”. Journal of Communication Inquiry 32/1 (2008) 60-82.

Etcoff N. \& Orbach S. (2004). Dove "The Real Truth About Beauty: A Global Report" Findings of the Global Study on Women, Beauty and Well Being. Source: http://www.clubofamsterdam.com/content articles/52\%20Beauty/dove_white_paper_final.pdf

Fairchild E. (2014). "Examining Wedding Ritual through a Multidimensional Gender Lens: The Analytic Importance of Attending to (In) Consistency” Journal of Contemporary Ethnography 43/3(2014) 361-389.

Howard V. (2003). “A “Real Man's Ring”: Gender and The Invention of Tradition”. Journal of History (2003) 837-856.

Humble A. M. , Zvonkovic A. M.\& Walker A. J. (2008). ““The Royal We” Gender Ideology, Display, and Assessment in Wedding Work”. Journal of Family Issues 29/1 (2008) 3-25.

Ingraham C. (1999). White Weddings, Romancing Heterosexuality in Popular Culture. New York 1999.

Lober J. (1994). Paradoxes of Gender. New Haven 1994.

Martin P. Y. (2004). “Gender as Social Institution”. Social Forces 82/4 (2004) 1249-1273. 
Montemurro B. (2005). “Add Men, don’t Stir: Reproducing Traditional Gender Roles in Modern Wedding Showers”. Journal of Contemporary Ethnography 34/1 (2005) 6-35.

Nash M. (2013). “Brides N’Bumps”. Feminist Media Studies 13/4 (2013) 593-612.

Neighbors L. A. \& Sobal J. (2008). "Weight and Weddings: Women's Weight Ideals and Weight Management Behaviors for Their Wedding Day”. Appetite 50 (2008) 550-554.

Otnes C. C. \& Pleck E. H. (2003). Cinderella Dreams, The Allure of the Lavish Wedding. Berkeley 2003.

Pepin J., Zimmerman T. S., Fruhauf C. A. \& Banning J. H. (2008). “An Analysis of Wedding Books for Grooms: A Feminist Perspective” Journal of Feminist Family Therapy 20/4 (2008) 328-356.

Prichard I. \& Tiggemann M. (2008). “An Examination of Pre-Wedding Body Image Concern in Brides and Bridesmaids”. Body Image 5 (2008) 395-398.

Prichard I. \& Tiggeman M. (2009). "Unveiled: Pre-wedding Weight Concerns and Health and Beauty Plans of Australian Brides”. Journal of Health Psychology 14/7 (2009) 1027-1035.

Prichard I., Polivy J., Provencher V., Herman C. P., Tiggeman M., Cloutier K. (2015). "Brides and Young Couples: Partners' Weight, Weight Change, and Perceptions of Attractiveness”. Journal of Social and Personal Relationships 32/2 (2015) 263-278.

Ridgeway C. \& Correll S. (2004). "Unpaking the Gender System: A Theoretical Perspectve on Cultural Beliefs in Social Relations”. Gender and Society 18 (2004) 510-531.

Risman B. (2004). “Gender as Social Structure”. Social Forces 82 (2004) 1249-1273.

Schweingruber D., Anahita S. \& Berns N. (2004). ““Popping the Question” When the Answer is Known: The Engagement Proposal as Performance”. Sociological Focus 37/2 (2004)143-161.

Schweingruber D., Cast A. D. \& Anahita S. (2008). ““A Story and a Ring”: Audience Judgments about Engagement Proposals”. Sex Roles 58 (2008) 165-178.

Sniezek T. (2005). “Is It Our Day or the Bride’s Day? The Division of Wedding Labour and Its Meaning for Coupes”. Qualitative Sociology 28/3 (2005) 215-234.

West C. \& Zimmerman D. (1987). “Doing Gender”. Gender and Society 1/2 (1987)125-151.

Winch A. \& Webster A. (2012). "Here Comes the Brand: Wedding Media and the Management of Transformation”. Continuum 26/1 (2012) 51-59.

\section{İnternet Erișimleri}

JADA (2004). “Here Comes to Bride... and Her Teeth are Nice and Bright!” JADA 134 (May1s 2004) 679. Kaynak: http://www.ada.org/ /media/ADA/Publications/Files/patient_38.ashx

PRNewswire (2016). “New Dove Research Finds Beauty Pressures Up, and Women and Girls Calling for Change”. PRNewswire (Haziran 2016). Kaynak: http://www.prnewswire.com/news-releases/newdove-research-finds-beautypressures-up-and-women-and-girls-calling-for-change-583743391.html

WBC Wedding Boot Camp (n.d.). http://www.weddingbootcamp.com/wedding-boot-camp

BRIDES The Best Bridal Boot Camps (2012). http://www.brides.com/gallery/best-bridal-boot-campswedding-fitness

Fitness Bridal Boot Camp: The Workout (n.d.). http://www.fitnessmagazine.com/weight-loss/ plans/wedding/bridal-bootcamp-workout/?page $=1$

Hopkins (2014). D. Hopkins, “The 1-Month Bridal Bootcamp Workout”. HARPER BAZAAR Kaynak: http://www.harpersbazaar.com/beauty/diet-fitness/advice/a2475/equinox-bridal-bootcamp/

Northwest Crossfit Offers Bride \& Groom Boot Camps (n.d.). http://www.nwcrossfit.com/northwestcrossfit-offers-bride-groom-boot-camps/ 